\title{
Mortars for laying and coating produced with iron ore tailings from tailing dams
}

\author{
Wanna Carvalho Fontes ${ }^{a}$, Júlia Castro Mendes ${ }^{a, *}$, Sidney Nicodemos Da Silva ${ }^{\mathrm{b}}$, \\ Ricardo André Fiorotti Peixoto ${ }^{\mathrm{a}}$ \\ a Laboratory of Materials for Civil Construction, Federal University of Ouro Preto, Ouro Preto CEP 35400-000, Brazil \\ ${ }^{\mathrm{b}}$ Materials Engineering Department, Federal Centre of Technological Education of Minas Gerais, Belo Horizonte CEP 30480-000, Brazil
}

\section{H I G H L I G H T S}

- Study of mortars with iron ore tailings (IOT): physical-mechanical properties.

- IOT present higher density than natural aggregates due to the iron concentration.

- Mortars with IOT showed mechanical properties fitter to brick laying than regular ones.

- Replacement up to $20 \%$ of lime by IOT granted satisfactory properties for coating.

- IOT morphology and voids required more mixing water to obtain plasticity in mortars.

\section{A R T I C L E I N F O}

\section{Article history:}

Received 17 December 2014

Received in revised form 22 February 2016

Accepted 5 March 2016

Available online 10 March 2016

\section{Keywords:}

Iron ore tailings from tailing dams

Recycled aggregates

Sustainable mineral binder

Sustainable mortars

\begin{abstract}
A B S T R A C T
Aiming to mitigate the environmental impact of the iron mining industry, this paper evaluates the technical feasibility of using iron ore tailings from tailing dams (IOT) as construction material, for mortars for laying and coating. Three mixtures were produced: conventional mortars, mortars with complete replacement of natural aggregate by IOT, and mortars replacing lime by IOT in proportions from $10 \%$ to $100 \%$. IOT and mortars were characterised. Mortars with IOT showed increased bulk density, reduced levels of incorporated air, an increment in the amount of mixing water, and improved mechanical properties when compared with conventional ones.
\end{abstract}

(c) 2016 Elsevier Ltd. All rights reserved.

\section{Introduction}

Every day, it is clearer to society that sustainable solutions are among the main responsibilities of an organisation. Recently, the increasing demand of better quality built environments, especially in developing countries such as BRICs [1], has required higher productivity from the construction and mining sectors. In order to meet the new urban development requirements, combined with greater environmental awareness of the population, new products and construction techniques have promoted advances in terms of environmental management. It is worth noticing that only in Brazil around 100 million tons of mortar per year are consumed [2], and 184 million tons of iron ore tailings are generated annually [3].

\footnotetext{
* Corresponding author.

E-mail addresses: wannarquit@gmail.com (W.C. Fontes), jcmendes.eng@gmail. com (J.C. Mendes), sidneynicodemos@yahoo.com.br (S.N.D. Silva), ricardofiorotti@ yahoo.com.br (R.A.F. Peixoto).
}

These facts favour the proposal of alternatives that contribute to the sustainability of construction and mining activities.

The Brazilian mineral industry has been engaged in the execution of environmental management programs that prioritize the reduction of the waste volume, proper disposal of waste, and enhancing the maintenance and monitoring of tailings dams [4]. However, such measures are not always enough to ensure the durability of these structures. As example, the current failure of two dams at the Germano plant, in Mariana, which led to the release of 62 million cubic meters of iron ore tailings [5]. This episode led to several human deaths and generated an expressive environmental impact, compromising the land for decades due to extensive area contaminated by mud, as shown in Fig. 1. In addition to this incident, other cases [6-8] also encourage more effective actions regarding management and safety of tailing dams.

Likewise, other countries have encouraged studies aimed at the reuse of iron mining waste in the development of new materials for construction [9-13]. Some of these studies have shown the 

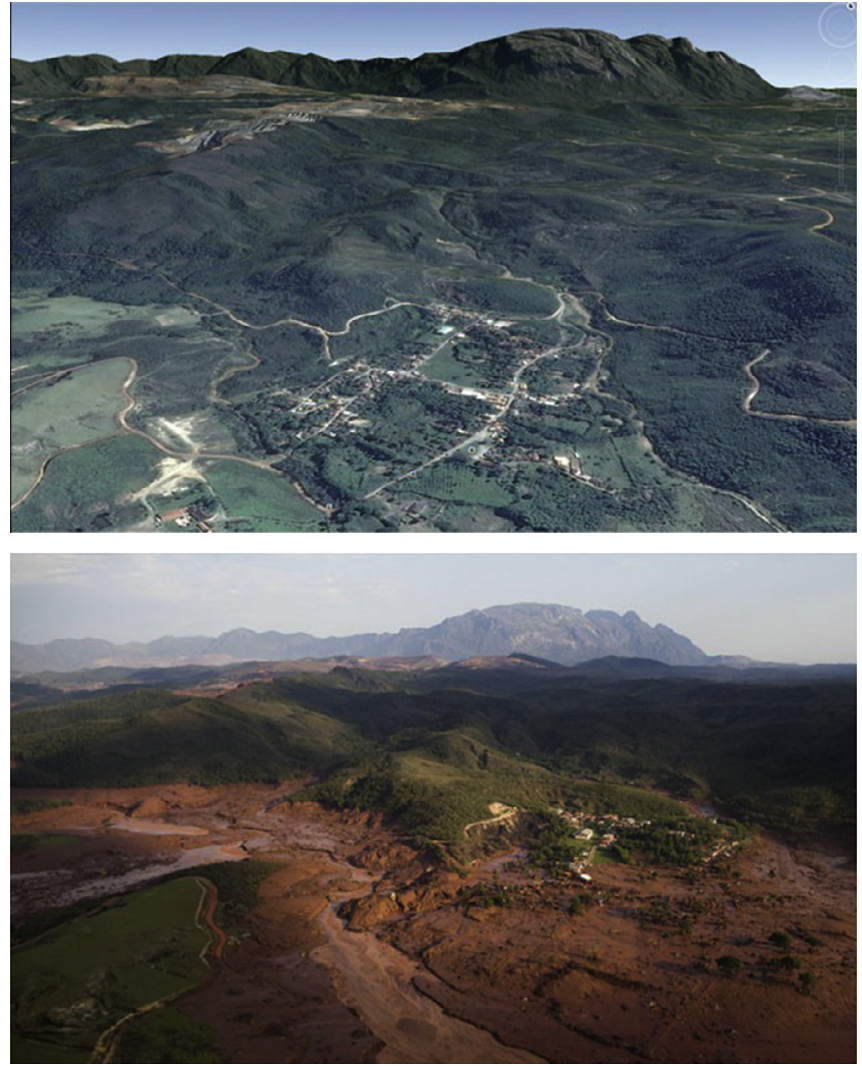

Fig. 1. Bento Rodrigues, district of Mariana, before and after the failure of the tailing dam [5].

use of iron ore tailings (IOT) as recycled aggregate is technically feasible; in addition to providing improved mechanical properties $[9,12,13]$.

IOT comprise fine materials mainly containing silica, together with iron oxides, alumina and other minor minerals. This constitution indicates their potential as construction material, such as aggregate for mortar and concrete $[9,12,13]$. In this context, the present work proposes the use of IOT as replacement for natural aggregates and lime in the production of mortars for coating and laying bricks.

\section{Materials and methods}

\subsection{Materials}

Portland cement type CP-III 40 RS was used in the preparation of the mortars. This designation refers to a hydraulic binder obtained by the homogeneous mixture of clinker and granulated blast furnace slag; with low heat of hydration; stable in the presence of reactive aggregates and resistant to sulphates. Its physicalmechanical specifications are displayed in Table 1, and fulfil Brazilian regulations requirements from ABNT NBR 5735 [14] and ABNT NBR 5737 [15]. Table 2 exhibits the composition of the cement.

In turn, the hydraulic lime adopted, type $\mathrm{CH} \mathrm{I}$, presents flow value of $123.75 \mathrm{~mm}$; water retention threshold higher than $80 \%$; and expansive substances absent, which provides greater stability. The chemical composition of the lime is shown in Table 3; it is in conformity with the parameters established by ABNT NBR 7175 [16]. The natural sand used as aggregate in the mortar mixtures is essentially comprised by silicon oxides [17].

In turn, the IOT used in different experimental models as binder and aggregate for mortars consists essentially of silica, alumina and hematite. Its detailed composition, obtained through X-ray Fluorescence (XRF) and X-ray Diffraction (XRD), is shown in Section 3.1. The IOT used in the present work originates from the margins of an iron ore tailing dam located in the state of Minas Gerais, Brazil. It is noteworthy that the iron ore tailings present heterogeneous characteristics in response to differences in the ore beneficiation processes, the type of raw ore, the variability of mining fronts, and even its position on the tailing dam [18].
Table 1

Physical-mechanical performance of Portland cement type CPIII 40RS.

\begin{tabular}{|c|c|c|c|c|c|c|}
\hline & \multicolumn{3}{|c|}{$\begin{array}{l}\text { Compressive } \\
\text { strength (MPa) }\end{array}$} & \multirow[t]{2}{*}{$\begin{array}{l}\text { Blainer } \\
\left(\mathrm{cm}^{2} / \mathrm{g}\right)\end{array}$} & \multirow{2}{*}{$\begin{array}{l}\text { Initial } \\
\text { set } \\
(\mathrm{min})\end{array}$} & \multirow{2}{*}{$\begin{array}{l}\text { Final } \\
\text { set } \\
(\mathrm{min})\end{array}$} \\
\hline & 3 days & 7 days & 28 days & & & \\
\hline Normative requirements & $\geqslant 12$ & $\geqslant 23$ & $\geqslant 40$ & - & $\geqslant 60$ & $\leqslant 720$ \\
\hline $\begin{array}{l}\text { Cement type "CPIII } \\
\quad 40 \text { RS" }\end{array}$ & 21 & 31 & 45 & 4500 & 200 & 285 \\
\hline
\end{tabular}

a Source: manufacturer (Cimentos Cauê).

\subsection{Characterisation of aggregates}

The preparation of samples for testing followed the methods prescribed by Brazilian standards. The natural aggregate and IOT were oven-dried $\left(105-110{ }^{\circ} \mathrm{C}\right)$. The IOT clay lumps and friable particles were broken down in a jaw crusher (RETSCH, model BB 200) and later comminuted in a jar mill with steel spheres (MARCONE, model MA 500). The obtained material was sieved and again subjected to comminution in a high efficiency jar mill with steel spheres (RETSCH, model BB 200 ), in order to dissociate all minerals present in the sample and improve the results of chemical and mineralogical characterisation. Finally, the samples were conditioned in airtight containers.

The IOT samples were chemically analysed with XRF, and their mineral composition was obtained with XRD. The equipment used was brand Shimadzu, models EDS-720 and XRD 7000, respectively. The Scanning Electron Microscope (SEM), a Shimadzu Superscan SSX-550, was able to display the microstructure of the tailings. Environmental analysis of leaching and solubilisation were performed on the raw material. This analysis followed the requirements of ABNT NBR 10007 [19], for sampling, ABNT NBR 10005 [20], for leaching test, and ABNT NBR 10006 [21], for solubilisation test. The IOT was then classified according to ABNT NBR 10004 [22].

Moreover, both IOT and natural aggregates were subjected to the following tests: particle size distribution (by mechanical shaker and laser diffraction), moisture content, bulk density, absolute density, and friability; all in accordance with standards ABNT NBR NM 248 [23], ABNT NBR 9939 [24], ABNT NBR NM 52 [25], ABNT NBR NM 45 [26] and ABNT NBR 7218 [27], respectively.

\subsection{Composition and moulding of mortars Specimens}

The mortars were produced with mix ratio 1:3 (binder:aggregate) $[12,23,24]$. Three conventional mixtures were produced as reference (TN1, TN2 and TN3), comprising natural aggregate, cement and lime. In three other mixtures, the natural aggregate was totally replaced by IOT (TR1, TR2 e TR3) with particle size above $75 \mu \mathrm{m}$ (TR1, TR2 e TR3). In the last four mixtures, the lime was partially replaced by IOT with particle size below $75 \mu \mathrm{m}$, in proportion of $10 \%$ (TS10), 20\% (TS20), $50 \%$ (TS50) and 100\% (TS100). The experimental planning of these mixtures is detailed in Table 4.

The specimens were moulded according to standard specification, ABNT NBR 13279 [28]. All specimens were removed from their moulds in $24 \mathrm{~h}$ and remained for 3,7 and 28 days in a curing chamber at $25^{\circ} \mathrm{C}$ and relative humidity of $60 \%$.

\subsection{Characterisation of mortars}

A fresh state characterisation was conducted, including tests for consistency index, water retention, bulk density and entrained air content through the pressure method, according to the equipment manufacturer manual. The consistency index corresponds to the water/cement ratio required for a prescribed flow of $260( \pm 5)$ $\mathrm{mm}$.

After curing, the specimens were subjected to bulk density test, compressive strength, flexural tensile strength, sorptivity and capillarity coefficient determination. All tests were conducted based on Brazilian normative requirements, ABNT NBR 13281 [29].

The preparation of mixtures was performed according to standard ABNT NBR 13279 [28]. To study the physical and mechanical properties of the mortar in the hardened state, 3 prismatic specimens were used for each test $40 \times 40 \times 160 \mathrm{~mm}$. They were demoulded after $24 \mathrm{~h}$ and maintained for 3,7 , and 28 days in a curing chamber at $25{ }^{\circ} \mathrm{C}$ and relative humidity of $60 \%$ [28].

\section{Results and discussion}

\subsection{Characterisation of aggregates}

Throughout the year 2011, every working day a new sample of IOT was obtained and chemically analysed with XRF. The results indicate that the IOT consists basically of hematite, silica and 
Table 2

Composition of Portland cement type CPIII 40 RS. ${ }^{\text {a }}$

\begin{tabular}{|c|c|c|c|c|c|c|c|c|c|c|}
\hline Components & $\mathrm{SiO}_{2}$ & $\mathrm{Fe}_{2} \mathrm{O}_{3}$ & $\mathrm{Al}_{2} \mathrm{O}_{3}$ & $\mathrm{CaO}$ & $\mathrm{MgO}$ & $\mathrm{K}_{2} \mathrm{O}$ & $\mathrm{CO}_{2}$ & $\mathrm{SO}_{3}$ & Loss on ignition $\left(1000^{\circ} \mathrm{C}\right)$ & Insoluble residue \\
\hline Proportion (\%) & 26.06 & 8.46 & 1.94 & 53.81 & 3.2 & 0.5 & 1.25 & 2.46 & 2.38 & 0.40 \\
\hline
\end{tabular}

a Source: manufacturer (Cimentos Cauê).

Table 3

Chemical composition of hydraulic lime type $\mathrm{CH}$ I. ${ }^{\mathrm{a}}$

\begin{tabular}{|c|c|c|c|c|c|c|c|c|}
\hline Components & $\mathrm{CaO}$ & $\mathrm{MgO}$ & $\mathrm{SiO}_{2}$ & $\mathrm{Fe}_{2} \mathrm{O}_{3}$ & $\mathrm{Al}_{2} \mathrm{O}_{3}$ & $\mathrm{SO}_{3}$ & $\mathrm{CO}_{2}$ & Loss by Calcination \\
\hline Proportion (\%) & 72.37 & 0.39 & 1.77 & 0.16 & 0.36 & 0.21 & 4.16 & 24.51 \\
\hline
\end{tabular}

${ }^{\text {a }}$ Source: manufacturer (Ical).

Table 4

Mortar mixture ratio (in volume).

\begin{tabular}{|c|c|c|c|c|c|c|c|c|c|c|}
\hline Materials & TN1 & TN2 & TN3 & TR1 & TR2 & TR3 & TS10 & TS20 & TS50 & TS100 \\
\hline Cement & 1 & 0.5 & - & 1 & 0.5 & - & 0.5 & 0.5 & 0.5 & 0.5 \\
\hline Lime & - & 0.5 & 1 & - & 0.5 & 1 & 0.45 & 0.4 & 0.25 & - \\
\hline Iron ore tailings & - & - & - & 3 & 3 & 3 & 0.05 & 0.1 & 0.25 & 0.5 \\
\hline Natural aggregates & 3 & 3 & 3 & - & - & - & 3 & 3 & 3 & 3 \\
\hline
\end{tabular}

alumina, containing less representative amounts of manganese and potassium. This inexpressive amount is believed not to affect the durability of the mortars. The average percentage of the chemical components is shown in Table 5.

The mineralogical composition of the IOT was verified by XRD where the most intense diffracted peaks of each crystal phase are shown in Fig. 2. The characteristic peaks of quartz and hematite were detected in the sample, as well as the kaolinite peak $\left(\mathrm{Al}_{2} \mathrm{Si}_{2}\right.$ $\left.\mathrm{O}_{5}(\mathrm{OH})_{4}\right)$. These results are in agreement with the results of the chemical analysis (XRF) and describe a stable and crystalline material, capable of serving as a building material in civil construction.

Morphological analysis of IOT particles were obtained by SEM magnified by $1000 \times$ (Fig. 3) and $2400 \times$ (Fig. 4). These pictures indicate the existence of a volumetric system comprising particulate grains with well-defined shape and various sizes. The SEM images show volumetric particles associated with hematite and quartz grains, identified by EDS. Probably the adhesion of the smaller flat grains to the larger grains of quartz and hematite (Fig. 2) will contribute to increasing the voids in the material. This phenomenon may demand larger quantities of mixing water in order to obtain consistency and plasticity required for mortars.

Figs. 5 and 6 display the natural aggregate and IOT particle size distribution, along with the limits for optimum zone and recommended usable zone defined by standards. It is noticeable that IOT is a particularly fine material (more than $50 \%$ of the material has particle size less than $75 \mu \mathrm{m}$ ); consequently, the particle size distribution of IOT is off the useable zone. The IOT showed a maximum dimension of $2.4 \mathrm{~mm}$ and the natural aggregate, $4.8 \mathrm{~mm}$. The fineness modules were respectively $0.61 \mathrm{~mm}$ and $1.56 \mathrm{~mm}$. This data reinforces what was observed in the morphological analysis of grains.

Further results of the tests of characterisation of IOT and natural aggregate are described in Table 6 . An analysis of these results shows that the moisture content [23] in the IOT is about five times that of the natural aggregate, due to the large presence of fines in the former. The IOT presented absolute density [25] 31.7\% higher than the natural aggregate and bulk density [26] 22.95\% higher, as a result of the high percentage of iron, around $45 \%$ in the IOT, as shown by the XRF. It was also found that IOT forms agglomerations with relative ease [27].

According to the prescriptions of standards 10005/04 and $10006 / 04$, the iron ore tailing is classified as Class II A (not
Table 5

Average chemical composition of IOT.

\begin{tabular}{lllllll}
\hline Components & $\mathrm{SiO}_{2}$ & $\mathrm{Fe}_{2} \mathrm{O}_{3}$ & $\mathrm{Al}_{2} \mathrm{O}_{3}$ & $\mathrm{P}$ & $\mathrm{Mn}$ & $\begin{array}{l}\text { Loss on ignition } \\
\left(1000^{\circ} \mathrm{C}\right)\end{array}$ \\
\hline $\begin{array}{l}\text { Proportion average } \\
(\%)\end{array}$ & 24.19 & 45.92 & 4.82 & 0.096 & 0.025 & 4.06 \\
\hline
\end{tabular}

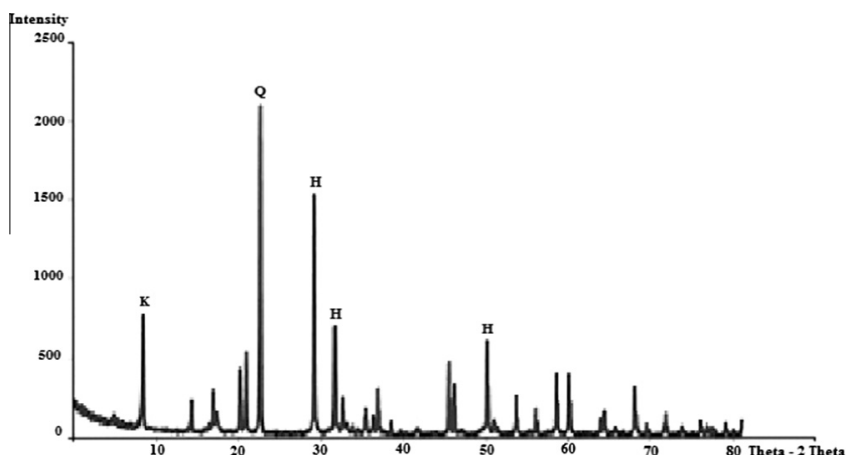

Fig. 2. XRD diffraction pattern of IOT. H: Hematite, Q: Quartz, K: Kaolinite

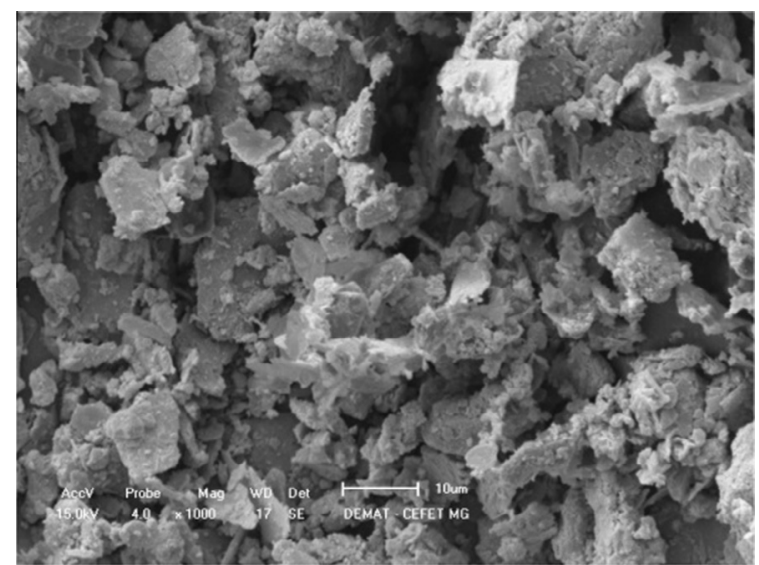

Fig. 3. SEM image of IOT $-1000 \times$. 


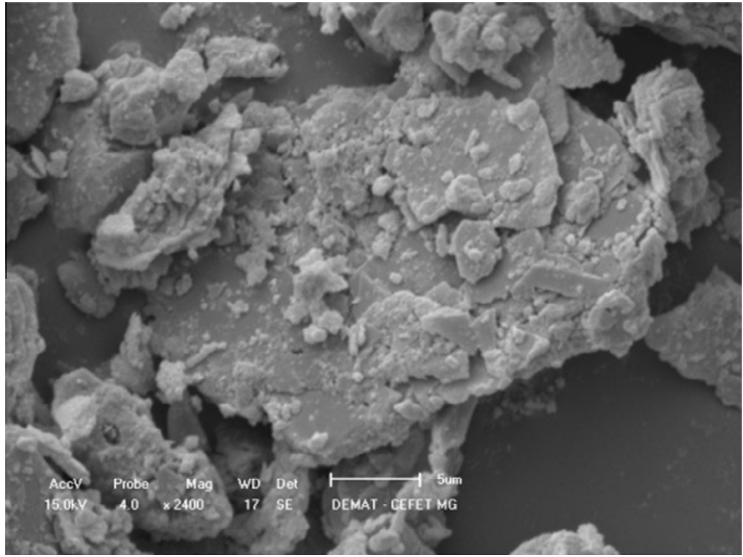

Fig. 4. SEM image of IOT $-2400 \times$.

dangerous - not inert), due to its iron and phenols content above the standard limit [22].

\subsection{Characterisation of mortars}

In the comparative analysis of Fig. 7 , it is noticeable that the higher the proportion of IOT in the mortar, the higher the required amount of water in order to reach the same flow (the consistency index); and, consequently, the capacity for air incorporation and water retention is lower. This is probably due to IOT fine particles (Fig. 5) and its morphological characteristics (see Figs. 3 and 4). The proportion of lime also affected the mortars plasticity, once lime, when dissolved in water, originates a saturated solution of $\mathrm{CaOH}_{2}$, which works as lubricant/flocculant among the particles of the aggregates. This fact explains the increase on the water amount as lime is gradually replaced by IOT on mixtures $\mathrm{TS}_{10}, \mathrm{TS}_{20}, \mathrm{TS}_{50}$ e $\mathrm{TS}_{100}$. The absorptive capacity of crystals which constitute the lime also contributes to the increased water retention in the mortar [30].

Regarding the aesthetic aspects of IOT coatings, these have a reddish coloration, which varies with the concentration of iron oxides, as shown in Fig. 8(a) and (b). It is noticeable that there was no occurrence of stains on the IOT coatings after the application and curing of the mortars, and even after 1 year of exposure to weather conditions.

In Fig. 8(a), it is observed that the great concentration of fines in the mortar TR2 promotes cracking due to drying shrinkage. On the other hand, when IOT is incorporated at lower concentration, as in mortar TS50, it acts as filler, closing off the existing voids in the mortar, not compromising its plasticity and contributing to its better mechanical performance Fig. 8(b).

The rapid loss of water, as observed in Fig. 8(a), compromises the mortar adherence, its ability to absorb deformation and its mechanical strength [30]. Therefore, the durability of the coating and sealing may also be compromised. The curing of the mortar comprising IOT occurs, in part, by simple drying process in which the mortar loses water, and its components remain sufficiently bonded, due to the binding characteristics of the IOT, as shown in Fig. 8(a) and (b). This binding capacity of the IOT is dictated by its components, their particles size and shape, and colloidal phenomena.

The results on Fig. 9 show that the increase of fines content in mortars comprising IOT contributed to their increased bulk density on the fresh state, compared with corresponding conventional mortars. The reason is, possibly, the increased packing of the grains and the higher value of absolute density of the IOT compared to the lime and natural aggregate. Another important aspect to consider is that the greater the bulk density of the mortar on the fresh state, the lower the workability, and thus the lower the productivity.

The cement mortars, TN1 and TR1, were denser in the hardened state than other mortars. This fact can be justified by the cement reaction with the mixing water, as this reaction produces a greater amount of products, and thereby results in mortars higher density. However, lime mortars, TN3 and TR3, have higher incorporated air content, which reflects in lower bulk density when hardened. It is also noticeable that the higher the proportion of IOT replacing lime, the greater the value of the bulk density of the mortar and the lower the incorporated air content, due to the chemical composition and particle size distribution of the recycled aggregate, as seen in Figs. 2 and 5.

In Fig. 10 are the results of the mortar sorptivity, as well as their capillary coefficients [29]. The mortars comprising IOT in replacement of the natural aggregate absorbed more water by capillarity than conventional mortar, which is justified by the lower dispersion of the lime solution in the mortar and by the large amount of fine particles. This higher sorptivity is also a function of the lower air content, once a well-distributed pore system interrupting the capillary channels prevent the water inlet [31]. As a measure of the inflow of water through the matrix, the sorptivity is related to the durability of cement-base composites [32]. However, there is no agreed limit for its modulus on the literature, technical or scientific, which could compromise the overall performance of the mortar.

It was also observed that the higher the lime content in the mortar, the greater the absorption coefficient due to the increased

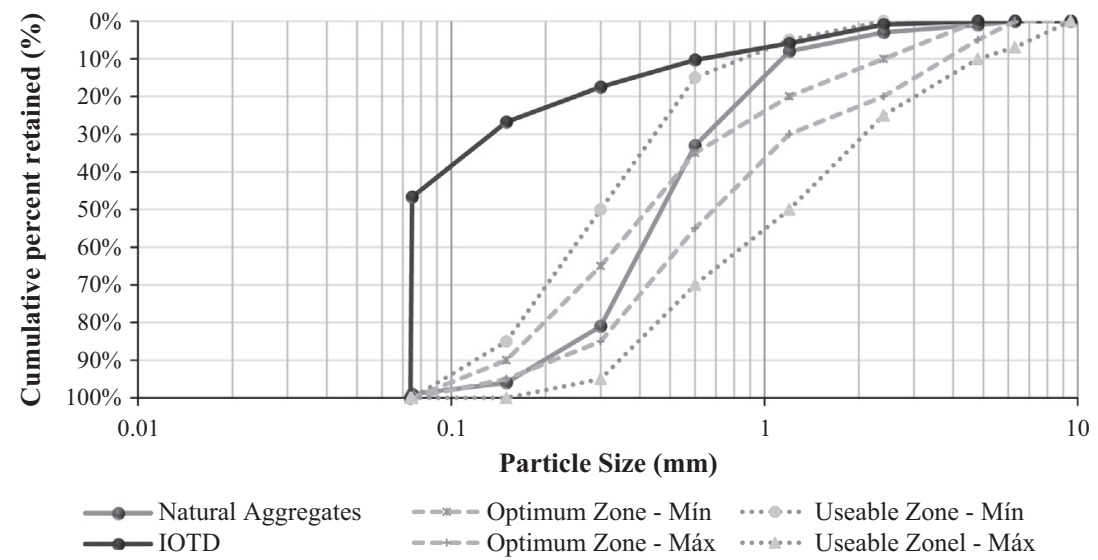

Fig. 5. IOT and natural aggregates particle size distribution using a mechanical sieve shaker. 


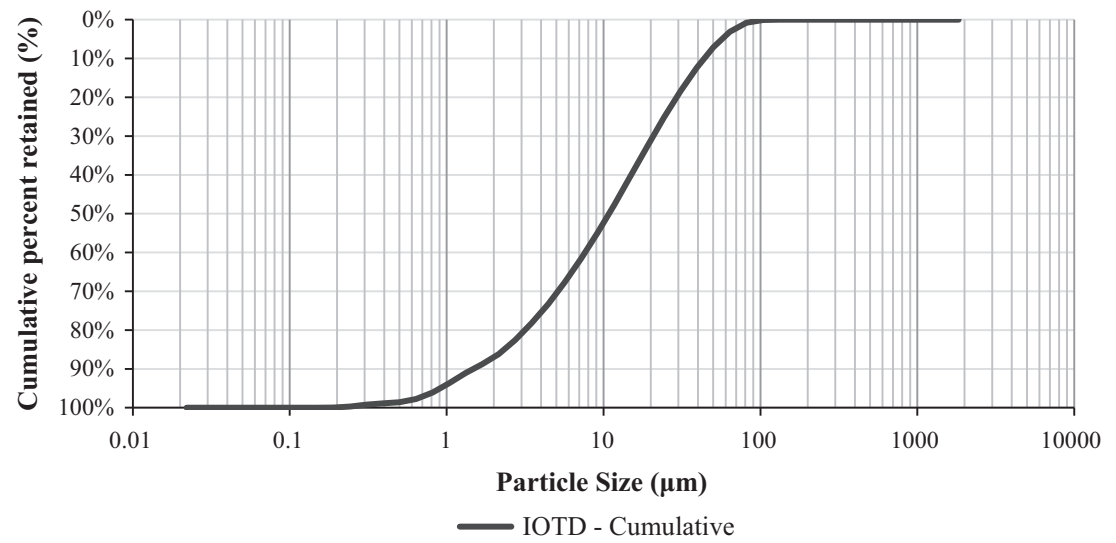

Fig. 6. IOT particle size distribution through laser particle size analyser.

Table 6

Physical characterisation of the aggregates, natural and recycled (IOT).

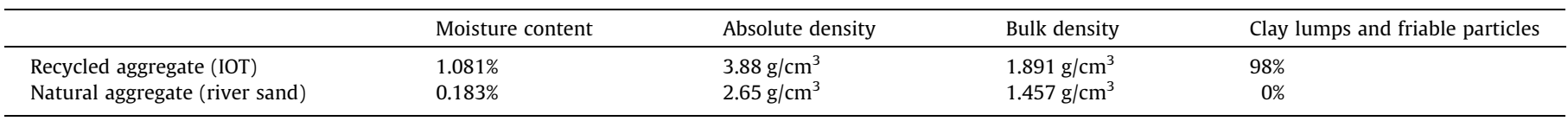

incorporation of air provided by the lime. This condition produces less rigid matrices, more deformable, and thus more suitable for the production of mortar for coating [33], according to Figs. 6 and 9.

The mechanical performance of mortars was evaluated by compressive tests and bending tests $[25,26]$, after the curing period of 7 and 28 days. In Fig. 11, the results show that the mortar incorporated with IOT presented better mechanical performance at 28 days when compared to conventional mortars, both in compressive and flexural strength. This observation is true for series TR, and TS, as the percentage of IOT increases, and it is less representative at the age of 7 days. In addition, it is possible to notice that the higher the ratio cement:IOT, the better the mechanical performance of the mortar, due to the IOT grain packaging phenomena by the products of the cement hydration, as mentioned before.

The compressive strength of TR 1 at 28 days is $15.4 \mathrm{MPa}, 13 \%$ higher than the 13.7 MPa of TN1. Similarly, mortars TR2 and TR3 are $128 \%$ and $67 \%$ more resistant than their conventional counterparts, TN2 and TN3, respectively. It is noticeable the strength gain from 7 to 28 days is more expressive for mortars with IOT as replacement of the natural aggregate. The compressive strength of mortar TR1 increased $130 \%$ when compared to its strength at
7 days, versus an increase of 57\% for TN1. An Analysis of Variance (ANOVA) at a significance level of $5 \%(\alpha=0.05)$ with the raw results of the specimens was performed. It showed no significant difference between TN1 and TR1 within the levels of acceptance, but stated that TN2 and TR2 are different, as are TN3 and TR3 (at 28 days). The results of the ANOVA for the TS series (in which lime was replaced by IOT) presented TS10 and TS20 as similar, but TS50 and TS100 different from them and between themselves. In addition, regarding the variation between the results at 7 and 28 days, the ANOVA comparison showed significant difference for the compressive strength of all the mixtures. However, the P-value of the natural mixtures (TN series) was 0.004 at average, when the Pvalue of the mixtures with IOT as aggregate (TR series) was lower than 0.0001. That means that the difference between the mean results at 7 and 28 days is more significant for the TR mortars.

In turn, the flexural strength of TR1 at 28 days is $4.0 \mathrm{MPa}, 24 \%$ higher than the 3.6 MPa of TN1. Similarly, mortars TR2 and TR3 are $144 \%$ and $269 \%$ more resistant than their conventional counterparts, TN2 and TN3, respectively. Similar to the results of the compressive strength, the flexural strength gain from 7 to 28 days is more expressive for mortars with IOT as replacement of the natural aggregate. The compressive strength of mortar TR1 increased $26 \%$

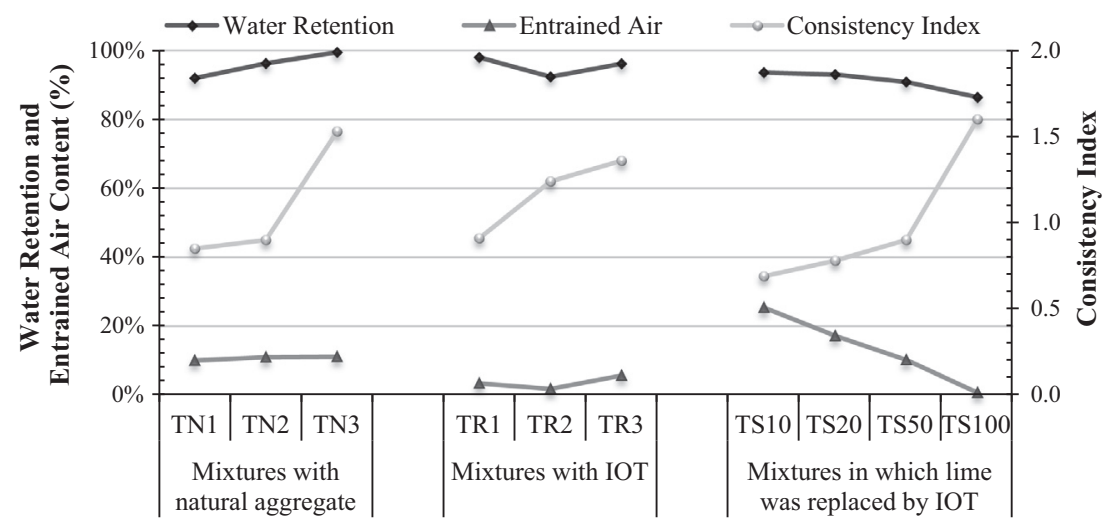

Fig. 7. Mortar characterisation: consistency index (water/binder ratio), water retention and incorporated air content. 


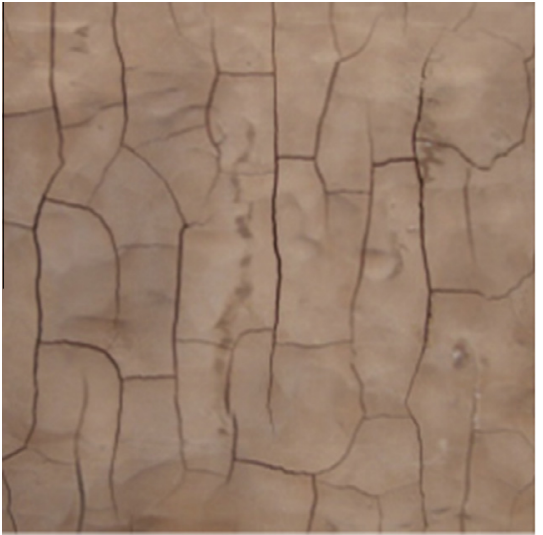

(a)

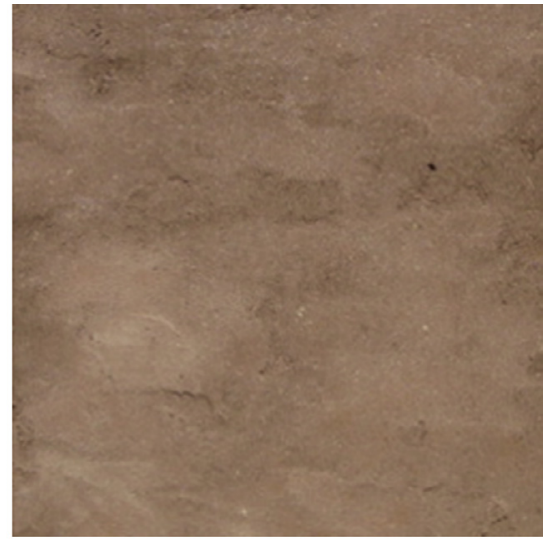

(b)

Fig. 8. Mortars for coating applied to surface, (a) mortar TR2, IOT in total replacement of natural aggregates; and (b) mortar TS50, 50\% lime replaced by IOT.

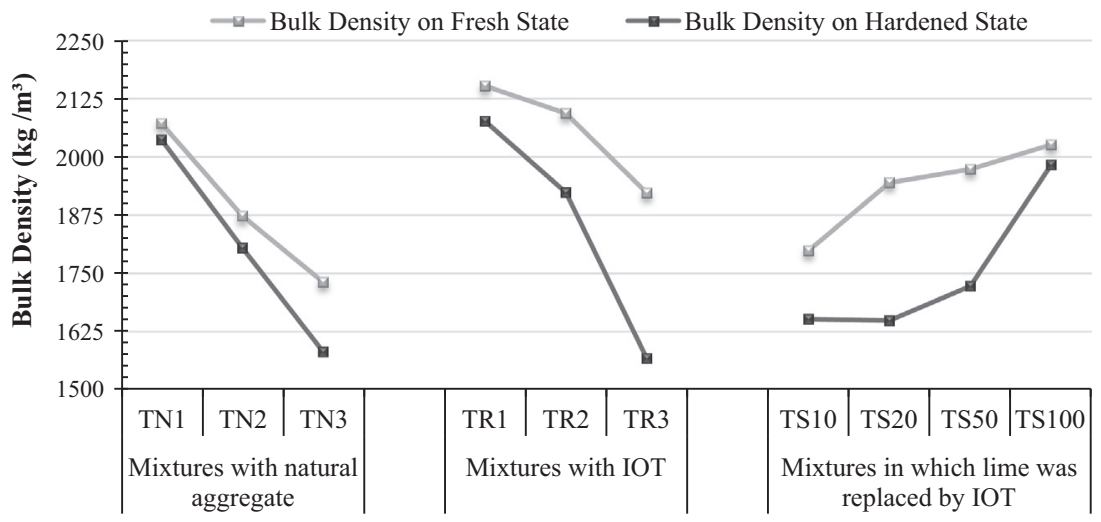

Fig. 9. Bulk density of mortars, on fresh state and hardened state.

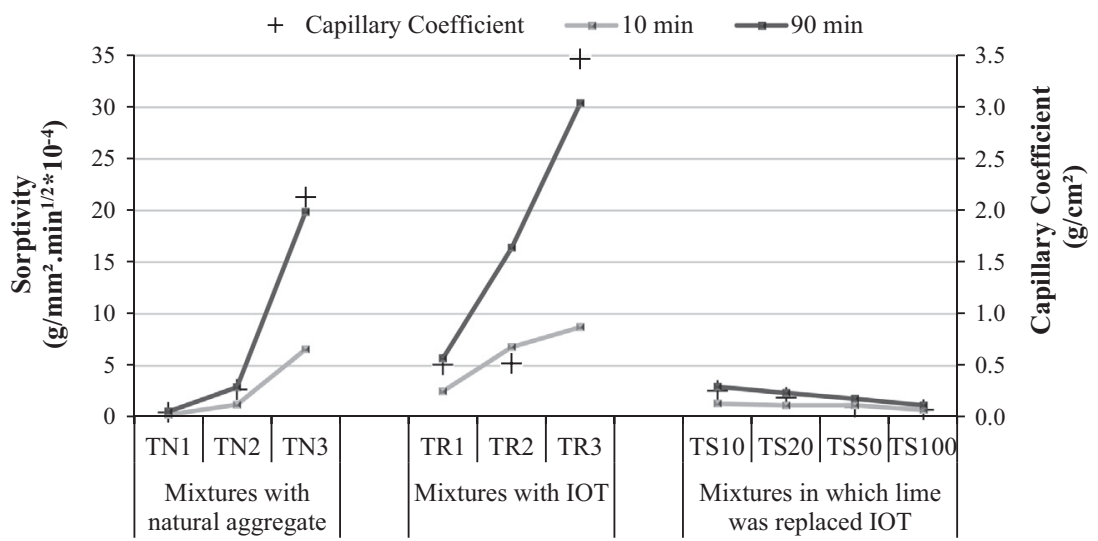

Fig. 10. Water absorption through capillary action, versus time.

when compared to its strength at 7 days, versus an increase of $79 \%$ for TN1. For TN2 and TN3, the increase was $60 \%$ and $78 \%$, respectively, lower values than $358 \%$ and $157 \%$ for TR2 and TR3. The Analysis of Variance showed that there is no significant difference between TN1 and TR1 within the levels of acceptance, but stated that TN2 and TR2 are different, as are TN3 and TR3 (at 28 days). Among the TS mortars, there is no significant difference. The ANOVA also showed that the mortars with natural aggregates and with IOT replacing lime have a similar flexural strength mean between 7 and 28 days, as opposite to mortars with recycled aggregate, in which this difference was significant.
The reason for this improved performance is that, with the IOT, the matrix becomes more continuous and provides a better medium for hydration products to be formed. In addition, the water/ cement ratio in IOT mortars is higher, also considering that a smaller mean diameter for recycled aggregates creates a structure with greater packaging. In turn, this structure produces a better interfacial stress transference between the materials [34], and retains water for a longer time, which explains the higher mechanical strength as a function of time.

Also, with the increased percentage of IOT as a replacement of lime, the air entrained is reduced due to the filler effect on the 


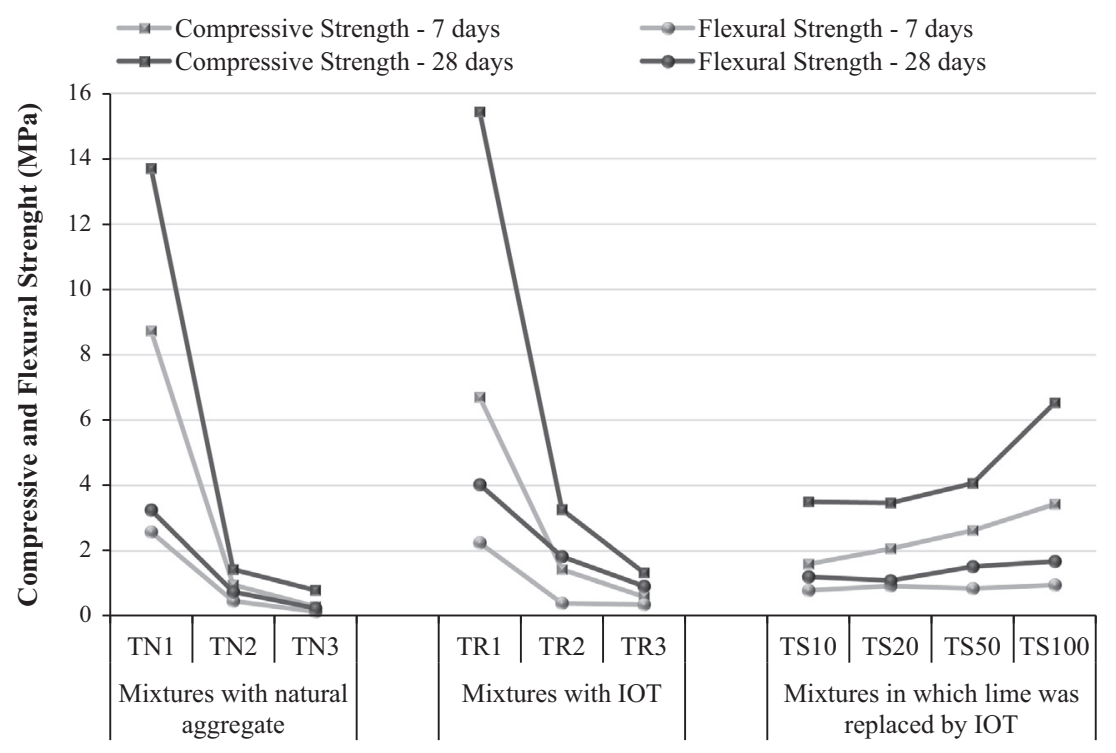

Fig. 11. Compressive strength and flexural strength.

matrices. Therefore, there is a tendency of improvement of the mechanical properties of the TR series as the IOT is added.

The increased compressive strength of the IOT mortars, along with its low air content, indicate a tighter matrix, and therefore, a more durable one.

\section{Conclusion}

Workability is one of the most important properties of mortars, especially for those destined for coating. In this sense, preliminary results indicate that the use of IOT in proportion not exceeding $20 \%$ in replacement of lime are more feasible for this application. For the same workability that of conventional mortars, the mortars produced with recycled aggregate (IOT), consumed higher contents of water for proper consistency and plasticity, but presented better mechanical performance at 28 days. They also display reduced entrained air content and greater bulk density in the fresh and hardened states, due to the high density of IOT. These properties indicate they are more appropriate for brick laying. In addition, the cracking presented on the TR series might compromise the durability of this type of mortar when applied to coatings.

Therefore, the present results encourage the use of IOT as construction material in the production of mortars for coating and laying of bricks. The authors suggest a further characterisation of the material in order to ascertain its applicability, such as durability and adherence tests.

It should be noticed that IOT is environmentally classified as Class II-A - non-dangerous and non-inert, and thus it does not present hazardous characteristics such as corrosivity, reactivity, toxicity, pathogenicity or flammability. The use of iron ore tailings from tailing dams as aggregate or filler will help reduce the exploitation of natural aggregates in deposits, as will contribute to the mitigation of environmental impacts of waste disposal. The use of IOT ultimately collaborates to the sustainability of construction and of all activities related to its supply chain.

\section{Acknowledgements}

We thankfully acknowledge the financial support provided from Brazilian research agencies CAPES, CNPq and FAPEMIG. We gratefully acknowledge the company Vale S.A., which supplied the tailings used in this research. We are also grateful for the infrastructure, encouragement and collaboration of the Research Group on Solid Wastes - RECICLOS - CNPq.

\section{References}

[1] IBRAM, Informações e Análises da Economia Mineral Brasileira, 7aㅡ edição. IBRAM, Belo Horizonte, 2012.

[2] ABAI, Associação Brasileira de Avaliação de Impacto, ABAI, São Paulo, 2014.

[3] FEAM, Inventário estadual de barragens do estado de Minas Gerais, FEAM, Belo Horizonte, 2012.

[4] S.F. Alves, A mineração está tentando fazer o seu dever de casa, Vale, 2009.

[5] G1, Tailings from Dams Reach Areas up to $100 \mathrm{~km}$ in MG 2015. Available at <http://g1.globo.com/minas-gerais/noticia/2015/11/hidreletrica-100-km-eafetada-por-lama-do-rompimento-de-barragens.html> (accessed 20/11/15).

[6] D. Kossoff, W.E. Dubbin, M. Alfredsson, S.J. Edwards, M.G. Macklin, K.A. Hudson-Edwards, Mine tailings dams: characteristics, failure, environmental impacts, Appl. Geochem. 51 (2014) 229-245.

[7] M. Davies, T. Martin, Mining market cycles and tailings dam incidents, AMEC earth \& environmental, Vancouver, British Columbia, in: Proceeding of the Thirteenth International Conference on Tailings and Mine Waste, Banff, Alberta, Canada, 2009.

[8] Z. Wei, G. Yin, J.G. Wang, L. Wan, L. Guangzhi, Design, construction and management of tailings storage facilities for surface disposal in China: case studies of failure, Waste Manage. Res. 31 (2013) 106-112.

[9] X. Huang, R. Ranade, W. Ni, V.C. Li, Development of green engineered cementitious composites using iron ore tailings as aggregates, Constr. Build. Mater. 44 (2013) 757-764.

[10] S. Zhao, J. Fan, W. Sun, Utilization of iron ore tailings as fine aggregate in ultrahigh performance concrete, Constr. Build. Mater. 50 (2014) 540-548.

[11] Z. Yong-Chao, N. Wen, X. Li, L. De-Zhong, Y.J.Z. Yong-Chao, Mechanochemical activation of iron ore tailings and preparation of high-strength construction materials, J. Univ. Sci. Technol. Beijing 32 (4) (2010) 504-508.

[12] F.L. Silva, F.G.S. Araújo, M.P. Texeira, R.C. Gomes, F.L. Vonkruger, Study of the recovery and recycling of tailings from the concentration of iron ore for the production of ceramic, Ceram. Int. 40 (2014) 16085-16089.

[13] M. Yellishetty, V. Karpe, E.H. Reddy, K.N. Subhash, Reuse of iron ore mineral wastes in civil engineering constructions: a case study - resources, Conserv. Recycl. 52 (2008) 1283-1289.

[14] Brazilian Association of Technical Standards (ABNT), NBR 5735: Blast Fumace Slag Portland Cement - Specification, ABNT, Rio de Janeiro, 1991.

[15] Brazilian Association of Technical Standards (ABNT), NBR 5737: Sulphate Resistent Portland Cements - Specification, ABNT, Rio de Janeiro, 1992.

[16] Brazilian Association of Technical Standards (ABNT), NBR 7175: Hydrated Lime for Mortars - Requirements, ABNT, Rio de Janeiro, 2003.

[17] W.C. Fontes, Utilização do rejeito de barragem de minério de ferro como agregado reciclado para argamassas de revestimento e assentamento (Dissertação (Mestrado)), Universidade Federal de Ouro Preto, Ouro Preto, 2013.

[18] L.F. D’agostino, Praias de Barragens de Rejeitos de Mineração: Características e Análise da Sedimentação (Tese (Doutorado)), Universidade de São Paulo, USP. São Paulo, 2008, p. 374p.

[19] Brazilian Association of Technical Standards (ABNT), NBR 10007: Sampling of Solid Waste, ABNT, Rio de Janeiro, 2004. 
[20] Brazilian Association of Technical Standards (ABNT), NBR 10005: Procedure fo Obtention of Leaching Extract of Solid Wastes, ABNT, Rio de Janeiro, 2004.

[21] Brazilian Association of Technical Standards (ABNT), NBR 10006: Procedure for Obtention of Solubilized Extraction of Solid Wastes, ABNT, Rio de Janeiro, 2004.

[22] Brazilian Association of Technical Standards (ABNT), NBR 10004: Solid Waste Classification, ABNT, Rio de Janeiro, 2004.

[23] Brazilian Association of Technical Standards (ABNT), NBR NM 248: Aggregates - Sieve Analysis of Fine and Coarse Aggregates, ABNT, Rio de Janeiro, 2003.

[24] Brazilian Association of Technical Standards (ABNT), NBR 9939: Coarse Aggregate - Determination of Total Moisture Content - Test Method, ABNT, Rio de Janeiro, 2011.

[25] Brazilian Association of Technical Standards (ABNT), NBR NM 52: Fine Aggregate - Determination of the Bulk Specific Gravity and Apparent Specific Gravity, ABNT, Rio de Janeiro, 2009.

[26] Brazilian Association of Technical Standards (ABNT), NBR NM 45: Aggregates - Determination of the Unit Weight and Air-Void Contents, ABNT, Rio de Janeiro, 2006
[27] Brazilian Association of Technical Standards (ABNT), NBR 7218: Aggregates Determination of Clay Lumps and Friable Materials, ABNT, Rio de Janeiro, 2010

[28] Brazilian Association of Technical Standards (ABNT), NBR 13279: Mortars Applied on Walls and Ceilings - Determination of the Flexural and the Compressive Strength in the Hardened Stage, ABNT, Rio de Janeiro, 2005.

[29] Brazilian Association of Technical Standards (ABNT), NBR 13281: Mortars Applied on Walls and Ceilings - Requirements, ABNT, Rio de Janeiro, 2005.

[30] Y. Sébaïbi, R.M. Dheilly, M. Quéneudec, Study of the water-retention capacity of a lime-sand mortar: influence of the physicochemical characteristics of the lime, Cem. Concr. Res. 33 (2003) 689-696.

[31] P. Mehta, P.J.M. Monteiro, Concrete: Microstructure, Properties and Materials, $2^{a}$ ed., IBRACON, São Paulo, 2014.

[32] B.B. Sabir, S. Wild, M. O'Farrel, A water sorptivity test for mortar and concrete, Mater. Struct./Matér. Constr. 31 (1998) 568-574.

[33] S. Tsimas, K. Raikos, Lime an irreplaceable mortar constituent, ZKG Int. 48 (6) (1995) 350-356.

[34] J. Young, S. Mindess, R. Gray, A. Bentur, The Science and Technology of Civil Engineering Materials, Prentice Hall, s.l., 1998. 